\title{
EFFECT OF MEDICINAL PLANTS ON HAEMATOLOGY AND SERUM BIOCHEMICAL PARAMETERS OF VILLAGE CHICKENS NATURALLY INFECTED WITH Heterakis gallinarum
}

\author{
M. Mwale ${ }^{1 *}$, P. J. Masika ${ }^{2}$ and S. A. Materechera ${ }^{1}$ \\ ${ }^{1}$ Indigenous Knowledge Systems Centre, Faculty of Agriculture, Science and Technology, North-West \\ University, Mafikeng Campus, Private Bag X2046, Mmabatho 2735, South Africa \\ ${ }^{2}$ Agricultural and Rural Development Research Institute (ARDRI), University of Fort Hare, Private Bag
} X1314, Alice 5700, South Africa

\begin{abstract}
The effects of Aloe ferox, Agave sisalana and Gunnera perpensa on haematological and biochemical parameters of village chickens naturally infected with Heterakis gallinarum were evaluated. One hundred and twelve mature village chickens were randomly allotted into 14 groups of 8 chickens. Group 1 and 2 were orally administered $1 \mathrm{~mL}$ distilled water for 4 consecutive days and $1 \mathrm{~mL}$ mebendazole (once), respectively. Groups 3-6 received $1 \mathrm{~mL}$ orally of aqueous leaf extract of A. ferox for 4 consecutive days, groups 7-10 A. sisalana and 11-14 G. perpensa in graded doses of 50, 100, $200 \mathrm{and} 400 \mathrm{mg} / \mathrm{kg}$, respectively. Blood was collected into vacutainers in triplicate, from the wing veins on day 0, 7 and 14. Data was analysed using general linear model of statistical analyses system. Chickens offered A. sisalana $(200 \mathrm{mg} / \mathrm{kg}) \mathrm{had}$ highest alanine transaminase (ALT) value $(P<0.05 ; 7.50 \pm 0.406 \mathrm{U} / \mathrm{l})$ on day 0 . On day 7 and 14 , there was no difference in ALT values $(P$ $>0.05$ ). Significant differences among plants for aspartate transaminase on day 0,7 and 14 were observed. Mean corpuscular haemoglobin concentration and mean corpuscular volume were maintained within the reference range. From day 0 to 14 , haematocrit was reduced for chickens on G. perpensa (50,100 and $400 \mathrm{mg} / \mathrm{kg})$, A. ferox (100 and $400 \mathrm{mg} / \mathrm{kg}$ ) and A. sisalana $(50,100,200$ and $400 \mathrm{mg} / \mathrm{kg})$. Haemoglobin was out of range on day 0 and improved to be within the range on day 7 and 14 . The medicinal plants enabled normal synthesis and functioning of haematological and biochemical parameters of village chickens and were maintained within the expected reference ranges. These plants are crucial phytomedicines for treating $H$. gallinarum infestations in village chickens.
\end{abstract}

Key words: Biochemical assay, chickens, full blood count; gastro-intestinal parasites, phytomedicine

\section{INTRODUCTION}

Medicinal plants have been used since ancient times for the control and treatment of human and livestock ailments (Ganesan and Bhatt, 2008). In particular, Aloe ferox, Agave sisalana and Gunnera perpensa are used in controlling gastro-intestinal parasites in village chickens (Dold and Cocks, 2001; van Wyk et al., 2008; Mwale and Masika, 2009). It has been observed that these plants are potentially toxic when used excessively (Mwale and Masika, 2011) but they have an invaluable efficacy against gastro-intestinal parasites in chickens (Brookes and Dutton, 2007; Yim et al., 2011), particularly H. gallinarum which is one of the most prevalence parasites in village chickens. Medicinal plants, however, contain some toxins that have multi-system effects, such as acute kidney injury accompanied by hepatitis and colitis (Swanepoel et al., 2008). In addition, plants may reduce levels of packed cell volume (PCV), red blood cells (RBC) and haemoglobin, significantly alter white blood cell value, and increase the levels of total protein, albumin and, aspartate transaminase (AST) and alanine transaminase (ALT) activity leading to impaired village chicken productivity (Adedapo et al., 2007). In some instances oral administration of plant extracts result in slight diarrhoea, catarrhal enteritis, degeneration of renal tubular cells, anorexia, ataxia, recumbence and death (Adam et al., 2001). These effects were related to serum lactic dehydrogenase and aspartate transaminase activities, concentrations of cholesterol, bilirubin, total protein, albumin, urea and haematological values (Adam et al., 2001).

In some cases, however, medicinal plants do not have harmful effects on haematological and serum biochemical parameters (Jaouad et al., 2004; Oduola et al., 2007). Haematological profiles both in humans and animals are an important index for the physiological state of an individual (Khan and Zafar, 2005). Haematology normally encompasses the evaluation of full blood count (FBC) and the organ involved in producing blood.

*Corresponding e-mail address: mukudzeishe@yahoo.com 


\section{Mwale and others}

The FBC parameters include RBC, platelets, haematocrit (packed cell volume), haemoglobin estimation, total and differential white blood cell counts and red blood cell indices; mean cell volume (MCV), mean corpuscular haemoglobin $(\mathrm{MCH})$ and mean corpuscular haemoglobin concentration (MCHC) (West and Haines, 2002). Full blood count gives information about the animal cells, providing its general health status. Abnormally high or low counts may indicate the presence of many forms of diseases, disease conditions or toxicity (West and Haines, 2002).

Haematological and biochemical parameters are, however, influenced by factors that include age, gender, feed, drugs, toxic compounds, diseases and parasite infestations (Agbede and Aletor, 2003; Huff et al., 2008; dos Santos Schmidt et al., 2009). Some medicinal plants are basically used as feed supplements for chickens or for medicinal purposes thereby becoming involved in a cascade of physiological reactions, that in turn lead to the alteration of haematological and serum biochemical parameters (Ewuola and Egbunike, 2008). This is necessitated by toxic substances that might be present in the plants in cases of lowering or elevating the haematological and biochemical values or non-toxic invaluable compounds that maintain the values in the expected reference ranges for chickens (Simaraks et al., 2004). In view of this, the toxicological effects of $A$. ferox, A. sisalana and G. perpensa on haematological and serum biochemical parameters of village chickens naturally infected with Heterakis gallinarum was evaluated. The hypothesis tested was that A. ferox, A. sisalana and $G$. perpensa do not elevate or lower the haematology and serum biochemical parameters of village chickens naturally infested with $H$. gallinarum.

\section{MATERIALS AND METHODS}

\section{Study site}

The study was conducted at Fort Cox College of Agriculture and Forestry $\left(32^{\circ} 46^{\prime} 23^{\prime \prime} \mathrm{S}\right.$ and $027^{\circ} 02^{\prime} 15^{\prime \prime} \mathrm{E}$; elevation $552 \mathrm{~m}$ ) in the Eastern Cape Province of South Africa. The college is in the False Thorn grassland that is associated with the semi-arid environment and the area receives an average annual rainfall of $480 \mathrm{~mm}$. Rain falls predominantly in the summer months (November-April) while June and July are the driest winter months. The Temperature ranges from $7^{\circ} \mathrm{C}$ in the cool dry season to $35^{\circ} \mathrm{C}$ in the hot dry season and the mean annual temperature is $18.7^{\circ} \mathrm{C}$. The vegetation is a mixture of trees, shrubs and grass species. The predominant grass species are Acacia karroo, Themeda triandra, Panicum maximum, Digitaria erientha, Eragrostis species and Cynodon dactylon. At the college livestock species reared include chickens, cattle, sheep and goats.

\section{Collection of plant material}

About $2 \mathrm{~kg}$ of fresh leaves of each of A. ferox, A. sisalana and G. perpensa were collected from Centane district (32 38' 63" S and 28 24' 36" E; elevation $50 \mathrm{~m}$ ) in the Eastern Cape Province of South Africa in October 2007. The plant materials were identified at Selmar Schonland Herbarium at Botany Department, Rhodes University, in South Africa. Voucher specimens (MMAN 2007/01), (MMAN 2007/02) and (MMAN 2007/03) for A. ferox, A. sisalana and G. perpensa, respectively were deposited in the Giffen Herbarium at the University of Fort Hare.

\section{Preparation of plant extracts}

The collected leaves were washed using cold water to remove dirt, following the smallholder farmers' procedures. Spines around the leaves of A. ferox and A. sisalana were removed using a knife. The leaves from the three medicinal plants were sliced before blending. Following the resource-poor farmers and herbalists' procedures, $200 \mathrm{~g}$ of each of the sliced A. ferox, A. sisalana and G. perpensa leaves were mixed with 100, 200 and $400 \mathrm{ml}$ of distilled water, respectively. The mixture for each of the plant material was blended with an electric blender for 3 minutes to obtain 200, 100 and 50\% (w/v) extract for A. ferox, A. sisalana and G. perpensa, respectively (Githiori et al., 2003). The blended material was squeezed through a muslin cloth. The extract from the three plants, recovered after squeezing through a muslin cloth was freeze-dried at $-50{ }^{\circ} \mathrm{C}$ under vacuum using a lyophilizer (Savant Refrigerated Vapor Trap, RVT 4104, USA) and kept in a freezer at $-20^{\circ} \mathrm{C}$ until use. One percent concentration was used to reconstitute the extracts to make A. ferox, A. sisalana and G. perpensa stock solutions. Thus, the extracts were reconstituted into 50, 100, 200 and $400 \mathrm{mg} / \mathrm{kg}$ doses. 
Haematology of parasite infested chickens

\section{Animals used}

A total of 112 mature village chickens of either sex, aged between 6 and 12 months, were acquired from

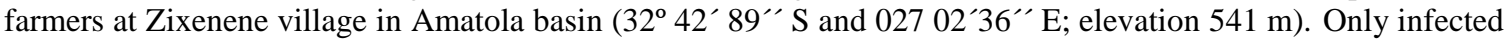
chickens were used and the modified quantitative McMaster (floatation) technique was used to determine faecal egg counts of H. gallinarum (MAFF, 1986). The average live weight of the chickens was $1.36 \mathrm{~kg} \pm 0.667$.

Ethical procedures for using village chickens were according to the University of Fort Hare ethics committee's and international standards (Austin et al., 2004; Marie, 2006) as well as in accordance with the Helsinki, 1964 ethical standards declared (World Medical Organization, 1996).

\section{Management of the chickens}

The village chickens $(n=112)$ were randomly alienated into 14 groups of eight chickens, and the initial weight of the chickens was recorded using a digital scale (August Sauter GmbH D-7470 Albstadt-Ebingen, Switzerland). Numbered plastic tags clipped onto the thighs of the chickens were used for identifying the chickens. The weight of chickens was uniform across treatments and was used for the calculation of doses (50, 100,200 and $400 \mathrm{mg} / \mathrm{kg}$ ). Chickens in group 1 (negative control) and 2 (positive control) were per os administered $1 \mathrm{~mL}$ distilled water for 4 consecutive days and $1 \mathrm{~mL}$ mebendazole (once), respectively. The other measurements and management were done for the negative control group except that instead of being given the plant extract under test, it was given distilled water. As for the positive group, the chickens received the same management as all the other chickens but $H$. gallinarum was controlled using mebendazole instead of any of the plant material extracts. The rest of the chickens were administered with $1 \mathrm{~mL}$ per os of the graded levels of the aqueous leaf extracts of the 3 medicinal plants for 4 consecutive days. Groups 3-6 received 50, 100, 200 and 400 $\mathrm{mg} / \mathrm{kg}$ of A. ferox, respectively, groups 7-10 received 50, 100, 200 and $400 \mathrm{mg} / \mathrm{kg}$ of A. sisalana, respectively and groups 11-14 received aqueous leaf extract of $G$. perpensa in the same respective doses.

The chickens were fed a mixture of maize and wheat bran at a ratio of 3:1 (EPOL Feeds Ltd, South Africa). Clean water was provided ad libitum. Each chicken received $100 \mathrm{~g}$ of feed per day. Feed offered and refusals were weighed daily using a digital scale (August Sauter GmbH D-7470 Albstadt-Ebingen, Switzerland), to avoid underfeeding the chickens.

\section{Blood parameter analyses}

Blood was collected pre-feeding in triplicate per treatment on day 0,7 and 14 using a syringe and a needle from the wing vein (Akhtar and Riffat, 1985; Hoque et al., 2006). Heparinised vacutainer tubes were used for the collection of blood for FBC while non-heparinised vacutainer tubes were used to collect blood for serum biochemical assay (AST and ALT). The haematological and serum biochemical parameters were determined using Advia 2120 (Bayer, Germany) for haematology and Beckman DXC 00 (USA) for serum chemistry, respectively. Haematological parameters assayed for were red blood cells (RBC), red cell distribution width, platelets, haematocrit, haemoglobin estimation, $\mathrm{MCV}, \mathrm{MCH}$ and $\mathrm{MCHC}$. Aspartate transaminase and ALT concentrations were assayed for from the serum (Burger et al., 2005). The reference range for haematological and serum biochemical parameters was according to Simaraks et al. (2004).

\section{Data analyses}

Data were tested for normality using proc univariate of the statistical analyses system (SAS, 2008). To confer normality data was transformed using square root. Data was analysed using the general linear model (GLM) procedure (SAS, 2008) to test the effect of A. ferox, A. sisalana and G. perpensa leaf extracts on haematological and serum biochemical parameters of village chickens.

\section{RESULTS}

The findings for biochemical assays obtained are reported as follows. There was a difference in ALT concentrations across the medicinal plants on day zero. Chickens offered A. sisalana $(200 \mathrm{mg} / \mathrm{kg})$ had the highest ALT value $(7.50 \pm 0.406 \mathrm{U} / \mathrm{l})$ followed by A. ferox $(400 \mathrm{mg} / \mathrm{kg})$ with $6.00 \pm 0.406 \mathrm{U} / \mathrm{l}$, while the rest of the chickens had low levels of ALT. Chickens in group 1 and 2 had the least ALT value of $4.00 \pm 0.406$ U/1. On day 7 , there was no difference in the ALT values of the chickens $(P>0.05)$ on all the treatments. 


\section{Mwale and others}

For AST, on day 0 chickens on A. ferox $50 \mathrm{mg} / \mathrm{kg}$ dose had the highest AST value (1 $416.50 \pm 93.590$ Ul) and those on distilled water had the least value of $222.33 \pm 93.590 \mathrm{Ul}$, while the rest of the chickens had

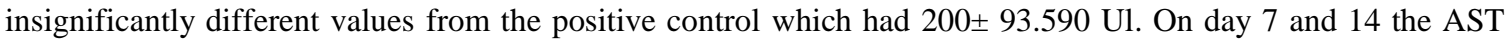
values were not different from the positive control $(P>0.05)$, except for chickens that were on distilled water which had a least AST value of $222.33 \pm 93.590$ Ul. For all dose levels, AST values did not change over time; from day 0 to $14(P>0.05)$, except for $A$. ferox $50 \mathrm{mg} / \mathrm{kg}$ where AST changed from $1416.50 \pm 93.590 \mathrm{Ul}$ at day 0 to $174.00 \pm 93.590$ and $175.00 \pm 93.590 \mathrm{Ul}$ at day 7 day 14 , respectively.

The findings for the full blood count observed are as follows. The MCHC value was high for chickens on mebendazole on day 0 and 7, respectively but was within the reference range for day 14 (Table 1). For $A$. sisalana $200 \mathrm{mg} / \mathrm{kg}$, MCHC was higher than the reference range on day 0 and within the range for day 7 and 14 . As indicated in Table 1, the same trend was noticed for A. ferox $400 \mathrm{mg} / \mathrm{kg}$ dose and G. perpensa 50,100 and $400 \mathrm{mg} / \mathrm{kg}$ doses. Chickens on G. perpensa $200 \mathrm{mg} / \mathrm{kg}$ on day 0 had the highest MCHC value of $47.00 \pm 0.885$ $\mathrm{g} / \mathrm{dl}$ but it decreased to $33.40 \pm 0.885 \mathrm{~g} / \mathrm{dl}$ on day 7 and increased to $40.07 \pm 0.885 \mathrm{~g} / \mathrm{dl}$ on day 14 . Chickens on $A$. ferox in all doses tested, together with A. sisalana 200 and $400 \mathrm{mg} / \mathrm{kg}$ had least MCHC values that were within the range at day 7.

The $\mathrm{MCH}$ values for chickens under treatment were not affected by the aqueous extracts of A. ferox, A. sisalana and $G$. perpensa; they were maintained within the reference range (33.0-47.0 pg) except for A. sisalana $100 \mathrm{mg} / \mathrm{kg}$ (day 7), G. perpensa $200 \mathrm{mg} / \mathrm{kg}$ (day 0), A. ferox 50 (day 14) and $200 \mathrm{mg} / \mathrm{kg}$ (day 0) doses that were higher than the reference range. On day 7, A. ferox (50 and $100 \mathrm{mg} / \mathrm{kg}$ ) and A. sisalana $(400 \mathrm{mg} / \mathrm{kg}$ ) were lower than the expected range. The aqueous leaf extracts of the test plants did not affect the MCV of chickens; they were all maintained within the reference range of 90.0-140.0 fl. Aloe ferox $50 \mathrm{mg} / \mathrm{kg}$ dose at day 14 exerted the highest MCV value $(116.50 \pm 1.563 \mathrm{fl})$ while $G$. perpensa $50 \mathrm{mg} / \mathrm{kg}$ at day 0 exerted the least value $(99.30 \pm$ $1.563 \mathrm{fl})$.

Table 1. The effect of Aloe ferox, Agave sisalana and Gunnera perpensa on mean corpuscular haemoglobin concentration in $\mathrm{g} / \mathrm{dl}(\mathrm{n}=24)$

\begin{tabular}{|c|c|c|c|c|c|}
\hline \multirow[t]{2}{*}{ Test material } & \multirow[t]{2}{*}{ Dose $(\mathrm{mg} / \mathrm{kg})$} & \multicolumn{3}{|c|}{$\operatorname{MCHC}^{1}\left( \pm \mathrm{SE}^{2}\right)$} & \multirow[t]{2}{*}{ Standard error } \\
\hline & & Day 0 & Day 7 & Day 14 & \\
\hline Distilled water & - & $36.77^{\mathrm{bc}}$ & $36.77^{\mathrm{bc}}$ & $36.77^{\mathrm{bc}}$ & 0.511 \\
\hline Mebendazole & $50 \mathrm{mg} / \mathrm{mL}$ & $40.60^{\mathrm{b}}$ & $40.87^{\mathrm{b}}$ & $33.90^{\text {cd }}$ & 0.511 \\
\hline \multirow[t]{4}{*}{ Aloe ferox } & 50 & $31.90^{\mathrm{cd}}$ & $28.07^{\mathrm{d}}$ & $41.20^{\mathrm{b}}$ & 0.885 \\
\hline & 100 & $30.80^{\mathrm{cd}}$ & $30.80^{\mathrm{d}}$ & $36.57^{\mathrm{bc}}$ & 0.885 \\
\hline & 200 & $43.60^{\mathrm{ab}}$ & $29.97^{\mathrm{d}}$ & $41.27^{\mathrm{b}}$ & 0.885 \\
\hline & 400 & $40.60^{\mathrm{b}}$ & $30.70^{\mathrm{cd}}$ & $37.43^{\mathrm{bc}}$ & 0.885 \\
\hline \multirow[t]{4}{*}{ Agave sisalana } & 50 & $38.00^{\mathrm{bc}}$ & $35.07^{\mathrm{c}}$ & $43.30^{\mathrm{ab}}$ & 0.885 \\
\hline & 100 & $34.50^{\mathrm{c}}$ & $43.30^{\mathrm{ab}}$ & $37.20^{\mathrm{bc}}$ & 0.885 \\
\hline & 200 & $36.30^{\mathrm{bc}}$ & $32.27^{\mathrm{cd}}$ & $33.90^{\text {cd }}$ & 0.885 \\
\hline & 400 & $35.50^{\mathrm{c}}$ & $27.47^{\mathrm{d}}$ & $42.30^{\mathrm{ab}}$ & 0.885 \\
\hline \multirow[t]{4}{*}{ Gunnera perpensa } & 50 & $38.40^{\mathrm{bc}}$ & $34.80^{\mathrm{c}}$ & $35.07^{\mathrm{c}}$ & 0.885 \\
\hline & 100 & $39.30^{\mathrm{bc}}$ & $39.40^{\mathrm{bc}}$ & $37.60^{\mathrm{bc}}$ & 0.885 \\
\hline & 200 & $47.00^{\mathrm{a}}$ & $33.20^{\mathrm{cd}}$ & $40.07^{\mathrm{b}}$ & 0.885 \\
\hline & 400 & $39.60^{\mathrm{bc}}$ & $35.30^{c}$ & $36.57^{\mathrm{bc}}$ & 0.885 \\
\hline Reference range & & & 26-35 & & \\
\hline
\end{tabular}

There was a difference in the haematocrit (packed cell volume) values of chickens treated with aqueous extracts of the test materials $(P<0.05)$ and that of the positive control. From day 0 to 14 , the values were mostly maintained within the range for chickens on distilled water, reduced for chickens on mebendazole, G. perpensa (50, 100 and $400 \mathrm{mg} / \mathrm{kg})$, A. ferox (100 and $400 \mathrm{mg} / \mathrm{kg}$ ) and A. sisalana (50, 100, 200 and $400 \mathrm{mg} / \mathrm{kg}$ doses); and increased for the rest of the doses. However, the values were within the reference range (Table 2). 
Haematology of parasite infested chickens

Table 2. Mean haematocrit values $( \pm \mathrm{SE})$ for village chickens administered with Aloe ferox, Agave sisalana and Gunnera perpensa

\begin{tabular}{|c|c|c|c|c|c|}
\hline \multirow[t]{2}{*}{ Test material } & \multirow[t]{2}{*}{ Dose $(\mathrm{mg} / \mathrm{kg})$} & \multicolumn{3}{|c|}{ Mean haematocrit values } & \multirow[t]{2}{*}{ Standard error } \\
\hline & & Day 0 & Day 7 & Day 14 & \\
\hline Distilled water & - & $0.28^{\mathrm{de}}$ & $0.28^{\mathrm{de}}$ & $0.28^{\mathrm{de}}$ & 0.007 \\
\hline Mebendazole & $50 \mathrm{mg} / \mathrm{mL}$ & $0.47^{\mathrm{a}}$ & $0.30^{\mathrm{d}}$ & $0.32^{\mathrm{c}}$ & 0.007 \\
\hline \multirow[t]{4}{*}{ Aloe ferox } & 50 & $0.31^{\mathrm{d}}$ & $0.33^{\mathrm{c}}$ & $0.40^{\mathrm{b}}$ & 0.012 \\
\hline & 100 & $0.40^{\mathrm{b}}$ & $0.31^{\mathrm{d}}$ & $0.27^{\mathrm{de}}$ & 0.012 \\
\hline & 200 & $0.26^{\mathrm{de}}$ & $0.30^{\mathrm{d}}$ & $0.34^{\mathrm{c}}$ & 0.012 \\
\hline & 400 & $0.35^{\mathrm{c}}$ & $0.25^{\mathrm{de}}$ & $0.27^{\mathrm{de}}$ & 0.012 \\
\hline \multirow[t]{4}{*}{ Agave sisalana } & 50 & $0.31^{\mathrm{d}}$ & $0.29^{\mathrm{d}}$ & $0.27^{\mathrm{de}}$ & 0.012 \\
\hline & 100 & $0.45^{\mathrm{ab}}$ & $0.22^{\mathrm{e}}$ & $0.28^{\mathrm{de}}$ & 0.012 \\
\hline & 200 & $0.38^{\mathrm{bc}}$ & $0.29^{\mathrm{d}}$ & $0.37^{\mathrm{bc}}$ & 0.012 \\
\hline & 400 & $0.40^{\mathrm{b}}$ & $0.28^{\mathrm{de}}$ & $0.29^{d}$ & 0.012 \\
\hline \multirow[t]{4}{*}{ Gunnera perpensa } & 50 & $0.33^{\mathrm{c}}$ & $0.25^{\mathrm{de}}$ & $0.27^{\mathrm{de}}$ & 0.012 \\
\hline & 100 & $0.42^{\mathrm{b}}$ & $0.27^{\mathrm{de}}$ & $0.28^{\mathrm{de}}$ & 0.012 \\
\hline & 200 & $0.21^{\mathrm{e}}$ & $0.24^{\mathrm{de}}$ & $0.28^{\mathrm{de}}$ & 0.012 \\
\hline & 400 & $0.33^{\mathrm{c}}$ & $0.25^{\mathrm{de}}$ & $0.26^{\mathrm{de}}$ & 0.012 \\
\hline Reference range & \multicolumn{5}{|c|}{$0.22-0.35$} \\
\hline
\end{tabular}

a, b, c, d, e Values with different superscripts are different at $P<0.05$. SE: Standard Error

Table 3. The effect of Aloe ferox, Agave sisalana and Gunnera perpensa on red blood cell count $\left(x 10^{6} \mu 1\right)(n=24)$

\begin{tabular}{|c|c|c|c|c|c|}
\hline \multirow[t]{2}{*}{ Test material } & \multirow[t]{2}{*}{ Dose (mg/kg) } & \multicolumn{3}{|c|}{ Red blood cell count $\left( \pm \mathrm{SE}^{1}\right)$} & \multirow[t]{2}{*}{ Standard error } \\
\hline & & Day 0 & Day 7 & Day 14 & \\
\hline Distilled water & - & $2.64^{\mathrm{c}}$ & $2.64^{\mathrm{c}}$ & $0.64^{\mathrm{c}}$ & 0.048 \\
\hline Mebendazole & $50 \mathrm{mg} / \mathrm{mL}$ & $4.21^{\mathrm{a}}$ & $2.68^{\mathrm{c}}$ & $3.05^{\mathrm{bc}}$ & 0.048 \\
\hline \multirow[t]{4}{*}{ Aloe ferox } & 50 & $2.93^{\mathrm{c}}$ & $2.96^{\mathrm{c}}$ & $3.46^{\mathrm{bc}}$ & 0.083 \\
\hline & 100 & $3.75^{\mathrm{ab}}$ & $2.93^{\mathrm{c}}$ & $2.61^{\mathrm{c}}$ & 0.083 \\
\hline & 200 & $2.42^{\mathrm{cd}}$ & $2.67^{\mathrm{c}}$ & $3.36^{\mathrm{bc}}$ & 0.083 \\
\hline & 400 & $3.36^{\mathrm{bc}}$ & $2.29^{\mathrm{cd}}$ & $2.56^{\mathrm{c}}$ & 0.083 \\
\hline \multirow[t]{4}{*}{ Agave sisalana } & 50 & $3.12^{\mathrm{bc}}$ & $2.67^{\mathrm{c}}$ & $2.63^{\mathrm{c}}$ & 0.083 \\
\hline & 100 & $3.97^{\mathrm{ab}}$ & $1.93^{\mathrm{d}}$ & $2.72^{\mathrm{c}}$ & 0.083 \\
\hline & 200 & $3.55^{\mathrm{ab}}$ & $2.85^{\mathrm{c}}$ & $3.43^{\mathrm{bc}}$ & 0.083 \\
\hline & 400 & $3.44^{\mathrm{bc}}$ & $2.62^{\mathrm{c}}$ & $2.80^{\mathrm{c}}$ & 0.083 \\
\hline \multirow[t]{4}{*}{ Gunnera perpensa } & 50 & $3.28^{\mathrm{bc}}$ & $2.32^{\mathrm{cd}}$ & $2.63^{\mathrm{c}}$ & 0.083 \\
\hline & 100 & $3.85^{\mathrm{ab}}$ & $2.42^{\text {cd }}$ & $2.65^{\mathrm{c}}$ & 0.083 \\
\hline & 200 & $2.06^{\mathrm{cd}}$ & $2.27^{\mathrm{cd}}$ & $2.75^{\mathrm{c}}$ & 0.083 \\
\hline & 400 & $3.10^{\mathrm{bc}}$ & $2.31^{\mathrm{cd}}$ & $2.52^{c}$ & 0.083 \\
\hline Reference range & \multicolumn{5}{|c|}{ 2.5-3.5 } \\
\hline
\end{tabular}

${ }_{\mathrm{a}, \mathrm{b}, \mathrm{c}, \mathrm{d}}$ Values with different superscripts are different at $P<0.05 . \mathrm{SE}^{1}$ : Standard Error

On day 0, blood platelets were higher than the reference range for mebendazole, G. perpensa $100 \mathrm{mg} / \mathrm{kg}, A$. ferox $100 \mathrm{mg} / \mathrm{kg}$ and $A$. sisalana 100, 200 and $400 \mathrm{mg} / \mathrm{kg}$ doses. At day 14 platelets were higher than the reference range only for $A$. ferox $50 \mathrm{mg} / \mathrm{kg}$. The least platelet value for the chickens was $3.00 \pm 0.993 \times 10^{9} / 1$ for mebendazole and $A$. ferox $50 \mathrm{mg} / \mathrm{kg}$ at day 0 and this increased to 11.00 and $17.00 \pm 0.993 \times 10^{9} / 1$ for mebendazole and $A$. ferox $50 \mathrm{mg} / \mathrm{kg}$ dose, respectively at day 7 and 14 . The highest value was $19.00 \pm 0.993 \times 10^{9} / 1$ for $A$. sisalana $50 \mathrm{mg} / \mathrm{kg}$. Agave sisalana $200 \mathrm{mg} / \mathrm{kg}$ dose exhibited a decrease from 10.00 and 10.50 to $3.00 \times 10^{9} / 1$ from day 0,7 and 14 , respectively.

The haemoglobin values of chickens were less than the expected range on day zero and improved to be within the range (7-13 g/dl) for day 7 and 14, for mebendazole, G. perpensa $100 \mathrm{mg} / \mathrm{kg}$, A. ferox $400 \mathrm{mg} / \mathrm{kg}$ and A. sisalana 100 and $400 \mathrm{mg} / \mathrm{kg}$. For A. ferox 50 and $200 \mathrm{mg} / \mathrm{kg}$ haemoglobin was higher than the reference range on 


\section{Mwale and others}

day 14. The red cell distribution width was not affected by the test medicinal plants $(P>0.05)$. As illustrated in Table 3, almost all the tested doses were within the reference range $\left(2.5-3.5 \times 10^{6} \mu \mathrm{l}\right)$ for red blood cell counts, except for mebendazole and the $100 \mathrm{mg} / \mathrm{kg}$ dose for A. sisalana, A. ferox and G. perpensa at day 0 , that were higher than the reference ranges.

\section{DISCUSSION}

Although, ALT and AST that represent serum glutamic-pyruvic transaminase (SPGT), which indicates how stressed the animal is due to parasite infestations among other factors like diseases, and integrity of the liver (Akhtar et al., 1985), were significantly different among the test materials throughout the experimental period, the values were within the reference range. This indicates that the plant extracts had constituents that assisted in relieving the chickens from stress caused by H. gallinarum infestation (Mungube et al., 2008; Shahadat et al., 2008). Khan and Zafar (2005) stated that changes in blood parameters signify stress, infection and intoxication. However, the current findings show that there was no possibly for acute and chronic liver damage as indicated by AST and ALT values which were not elevated or lowered beyond the expected reference range. This concurs with the findings for organs and biochemical values of rats where A. ferox and G. perpensa did not damage the livers of rats, or alter AST and ALT values (Mwale and Masika, 2011; 2012). However, A. sisalana caused an elevation of the AST and ALT levels in (Mwale et al., 2013).

The MCHC of the chickens was mainly within the range, although initially it was high and out of range, indicating that the aqueous leaf extracts of the test medicinal plants enabled the MCHC of the chickens to normalise. This indicates that the plants consist of invaluable compounds that lead to the improvement of haematological values of chickens. Improvement in the MCHC values could be that the plants were making the vitamin available that could have been depleted due to parasite infection. Similar findings were obtained for $\mathrm{MCH}$ and MCV blood components. In addition, the plants could have been providing iron necessary for the synthesis of haemoglobin, thereby enhancing MCHC levels. This indicates that the studied medicinal plants are pivotal in alleviating the effects of $H$. gallinarum that include anaemia, inflammation and pain. This supports the wide use of the plants by resource-limited farmers in controlling gastro-intestinal parasites in village chickens (Mwale and Masika, 2009). Findings of the current study are contrary to the findings by Fasuyi and Aletor (2005a) where in their study MCV were reduced and RBC increased in broiler chickens.

Similar to other medicinal plants which are rich in nutrients including minerals such as calcium, zinc and potassium (Fasuyi and Aletor, 2005b), the currently studied plants might be constituting essential nutrients especially zinc and iron that are essential for blood synthesis; therefore it is important to evaluate the nutritional profile of A. ferox, A. sisalana and G. perpensa. The authors alleged that RBC is the most consistently affected blood parameter since their cells are easily and rapidly broken down. However, in our study, RBC levels improved from day 0 to day 7 and 14, an indication that the plants may positively influence the synthesis of RBC levels in chickens thereby ameliorating the problem of anaemia due to parasite infestation. The current findings could be attributed to the anti-oxidant property that has been reported for A. ferox (Chun-hui et al., 2007; Loots et al., 2007) and G. perpensa (Steenkamp et al., 2004) that lead to minimised damage, prevention and repair of damage done by these free radicals of cells that produce RBC through the scavenging of free radicals and enhancement of the immune defence. This supports the assertion by the resource-limited farmers that these medicinal plants are effective in controlling gastro-intestinal parasites in village chickens (Dold and Cocks, 2001). It is therefore, paramount to scientifically validate and authenticate these assertions so as to add value and to preserve views of resource-limited farmers.

The observation that haemoglobin, haematocrit and platelets were within the expected range signifies that the plants under study could importantly influence the replenishment of lost blood thereby curbing anaemia that may be caused by $H$. gallinarum (Liebhart and Hess, 2009). The histomonas can cause liver damage leading to protein deficiency and hence anaemia (Sentíes-Cué et al., 2009), therefore synthesis and maintenance of haematological values within the reference range, is crucial as necessitated by the studied plants. The results are, however, contrary to those of Hoque et al. (2006) where haemoglobin and packed cell volume (haematocrit) increased in the study for testing the anthelmintic efficacy of pineapple leaf extract against natural ascariasis in indigenous chickens.

Aloe ferox, A. sisalana and G. perpensa positively influenced the haematological and biochemical values of village chickens. The parameters were maintained within the reference ranges and those that were higher than the 
reference range improved to be within the reference range. These medicinal plants are potentially useful phytomedicines for controlling and maintaining haematological effects impaired by $H$. gallinarum infestation in village chickens.

\section{ACKNOWLEDGEMENTS}

Authors are indebted to the National Research Foundation of South Africa for funding the project, the Department of Biochemistry and Microbiology, Nelson Mandela Metropolitan University, Port Elizabeth, South Africa; and the Department of Microbiology and Biochemistry, University of Fort Hare, Alice, South Africa; for assistance with freeze-drying of the plant materials. Authors acknowledge the assistance rendered by students at the University of Fort Hare, Livestock and Pasture Science Department.

\section{REFERENCES}

1. Adam SEI, Al-Yahya MA and Farhan AH (2001). Response of Najdi sheep to oral administration of Citrullus colocynthis fruits, Nerium oleander leaves or their mixture. Small Ruminant Research 40: 239-244.

2. Adedapo AA, Abatan MO and Olorunsogo OO (2007). Effects of some plants of the spurge family on haematological and biochemical parameters in rats. Veterinarski Arhive 77 (1): 29-38.

3. Agbede JO and Aletor VA (2003). Evaluation of fish meal replaced with leaf protein concentrate from Glyricidia in diets for broiler chicks: Effect on performance, muscle growth, haematology and serum metabolites. International Journal of Poultry Science 2 (4): 242-250.

4. Akhtar MS and Riffat S (1985). Evaluation of Melia Azedarach Linn. Fruit (Bakain) against Ascaridia galli infection in chickens. Pakistan Veterinary Journal 5 (1): 34-37.

5. Austin JC, du Toit DN, Fraser PL, Mansfield D, Macleod A, Odendaal JSJ and Seier J (2004). Guidelines on Ethics for Medical Research: Use of Animals in Research and Training. Medical Research Council 1-53.

6. Brookes KB and Dutton MF (2007). Bioactive components of the uteroactive medicinal plant, Gunnera perpensa (or ugobo). South African Journal of Science 103: 187-189.

7. Bürger C, Fischer DR, Cordenuzzi DA, Batschauer AP, Cechinel Filho V and Soares AR (2005). Acute and sub acute toxicity of the hydroalcoholic extract from Wedelia paludosa (Acmela brasiliensis) (Asteraceae) in mice. Journal of Pharmacy and Pharmaceutical Science 8 (2): 370-373.

8. Chun-hui L, Chang-hai W, Zhi-liang X and Yi W (2007). Isolation, chemical characterization and antioxidant activities of two polysaccharides from the gel and the skin of Aloe barbadensis Miller irrigated with sea water. Process Biochemistry 42 (6): 961-970.

9. Dold AP and Cocks ML (2001). Traditional veterinary medicine in the Alice district of the Eastern Cape Province. South Africa. South African Journal of Science 97: 375-379.

10. dos Santos Schmidt EM, Paulillo AC, Martins GRV, Lapera IM, Testi AJP, Junior LN, Denadai J and Fagliari JJ (2009). Haematology of the bronze turkey (Meleagris gallopavo): Variations with age and gender. International Journal of Poultry Science 8 (8): 752-754.

11. Ewuola EO and Egbunike GN (2008). Haematological and serum biochemical growing rabbit bucks fed dietary fumonisin. African Journal of Biotechnology 7 (23): 4304-4309.

12. Fasuyi AO and Aletor VA (2005a). Protein replacement value of Cassava (Manihot esculenta, Crantz) leaf protein concentrate (CLPC) in broiler starter: Effect on performance, muscle growth, haematology and serum metabolites. International Journal of Poultry Science 4 (5): 339-349.

13. Fasuyi AO and Aletor VA (2005b). Protein replacement value of Cassava (Manihot esculenta, Crantz) leaf protein concentrate (CLPC) in broiler starter: effect on performance, muscle growth, haematology and serum metabolites. International Journal Poultry Science 4 (5): 339-349.

14. Ganesan S and Bhatt RY (2008). Qualitative Nature of Some Traditional Crude Drugs Available in Commercial Markets of Mumbai, Maharashtra. India Ethnobotanical Leaflets 12: 348-360.

15. Githiori JB, Höglund J, Waller PJ and Baker L (2003). Evaluation of anthelmintic properties of extracts from some plants used as livestock dewormers by pastoralist and smallholder farmers in Kenya against Heligmosomoidespolygyrus infections in mice. Veterinary Parasitology 118: 215-226.

16. Hoque ME, Mostofa M, Awal MA, Choudhury ME, Hossain MA and Alam MA (2006). Comparative efficacy of piperazine citrate, levamisole and Pineapple leaves extract against naturally infected ascariasis in indigenous chickens. Bangladesh Journal of Veterinary Medicine 4 (1): 27-29.

17. Huff GR, Huff WE, Rath NC, Anthony NB and Nestor KE (2008). Effects of Escherichia coli challenge and transport stress on haematology and serum chemistry values of three genetic lines of turkeys. Poultry Science 87: 2234-2241. 
18. Jaouad ElH, Zafar HI and Badi^aa L (2004). Acute and chronic toxicological studies of Ajuga iva in experimental animals. Journal of Ethnopharmacology 91: 43-50.

19. Khan TA and Zafar F (2005). Haematological study in response to varying doses of oestrogen in broiler chicken. International Journal of Poultry Science 4 (10): 748-751.

20. Liebhart D and Hess M (2009). Oral infection of turkeys with in vitro-cultured Histomonas meleagridis results in high mortality. Avian Pathology 38 (3): 223-227.

21. Loots du T, van der Westhuizen FH and Botes L (2007). Aloe ferox leaf gel phytochemical content, antioxidant capacity, and possible health benefits. Journal of Agricultural and Food Chemistry 55 (17): 6891-6896.

22. MAFF (1986). Manual of Veterinary Parasitological Laboratory Techniques (ADAS, HMSO).

23. Marie M (2006). Ethics: The new challenge for animal agriculture. Livestock Science 103: 203- 207.

24. Mungube EO, Bauni SM, Tenhagen BA, Wamae LW, Nzioka SM, Muhammed, L and Nginyi JM (2008). Prevalence of parasites of the local scavenging chickens in a selected semi-arid zone of Eastern Kenya. Tropical Animal Health and Production 40: 101-109.

25. Mwale M and Masika PJ (2009). Ethno-veterinary control of parasites, management and role of village chickens in rural households of Centane district in the Eastern Cape of South Africa. Tropical Animal Health and Production 41 (8): 1685-93.

26. Mwale M and Masika PJ (2011). Toxicity evaluation of the aqueous leaf extract of Gunnera perpensa L. (Gunneraceae). African Journal of Biotechnology 10 (13): 2503-2513.

27. Mwale M and Masika PJ (2012). Toxicological Studies on the Leaf Extract of Aloe ferox Mill. (Aloaceae). Scientific Research and Essays 7 (15): 1605-1613.

28. Mwale M, Masika PJ and Materechera SA (2013). Assessment of the potential toxic effects of Agave sisalana Perrine ex Engelm in rats. Journal of Medicinal Plant Research 7 (34): 2514-2522.

29. Oduola T, Popoola GB, Avwioro OG, Oduola TA, Ademosun AA and Lawal MO (2007). Use of Jatropha gossypifolia stem latex as a haemostatic agent: how safe is it? Journal of Medicinal Plants Research 1 (1): 014 017.

30. Sentíes-Cué G, Chin RP and Shivaprasad HL (2009). Systemic histomoniasis associated with high mortality and unusual lesions in the bursa of fabricius, kidneys, and lungs in commercial turkeys. Avian Diseases 53 (2): 231-238.

31. Shahadat HM, Mostofa M, Mamun MAA, Hoque ME and Awal MA (2008). Comparative Efficacy of Korolla (Momordica Charantia) Extract and ivermec ${ }^{\circledR}$ pour on with their effects on certain blood parameters and body weight gain in indigenous chicken infected with Ascaridia Galli. Bangladesh Journal of Veterinary Medicine 6 (2): $153-158$.

32. Simaraks S, Chinrasri O and Aengwanich W (2004). Haematological, electrolyte and serum biochemical values of the Thai indigenous chickens (Gallus domesticus) in north eastern, Thailand. Songklanakarin Journal of Science and Technology 26 (3): 425-430.

33. Statistical Analytical Systems (SAS). 2008 SAS/STAT User's guide (Release 9.2 Edition). SAS Institute Inc. Cary, North Carolina.

34. Steenkamp V, Mathivha E, Gouws MC and van Rensburg CEJ (2004). Studies on antibacterial, antioxidant and fibroblast growth stimulation of wound healing remedies from South Africa. Journal of Ethnopharmacology 95 (23): 353-357.

35. Swanepoel C, Blockman M and Talmud J (2008). Nephrotoxins in Africa In: de Broe ME, George AP, Bennett WM and Deray G (Editors). Clinical nephrotoxins: Renal injury from drugs and chemicals. Part 3. Metapress, Springer, New York. p. 859-870.

36. van Wyk B-E, de Wet H and van Heerden FR (2008). An ethnobotanical survey of medicinal plants in the south eastern Karoo, South Africa. South African Journal of Botany 74: 696-704.

37. West GD and Haines VL (2002). Haematology and serum biochemistry values of captive Attwater's prairie chickens (Tympanuchus cupido attwateri). Journal of Zoo and Wildlife Medicine 33 (2): 122-124.

38. World Medical Organization (1996). Declaration of Helsinki, Finland 1964. British Medical Journal 313 (7070): 1448-1449.

39. Yim D, Kang SS, Kim DW, Kim SH, Lillehoj HS and Min W (2011). Protective effects of Aloe vera-based diets in Eimeria maxima-infected broiler chickens. Experimental Parasitology 127 (1): 322-325. 